\title{
Operational management of the cane infield wagon: Analysis of the cost of repair and maintenance
}

\author{
Cezario B. Galvão ${ }^{1}$, Angel P. Garcia ${ }^{1}$, Daneil Albiero ${ }^{2}$, Admilson Í. Ribeiro ${ }^{3}$ \& Ângelo D. Banchi ${ }^{4}$ \\ ${ }^{1}$ Universidade Estadual de Campinas/Faculdade de Engenharia Agrícola. Campinas, SP. E-mail: cezario.galvao@feagri.unicamp.br - ORCID: 0000-0001- \\ 9933-8586 (Corresponding author); angel.garcia@feagri.unicamp.br - ORCID: 0000-0002-8163-6638 \\ ${ }^{2}$ Universidade Federal do Ceará. Fortaleza, CE. E-mail: daniel.albiero@gmail.com - ORCID: 0000-0001-6877-8618 \\ ${ }^{3}$ Universidade Estadual Paulista Júlio de Mesquita Filho/Campus Experimental de Sorocaba. Sorocaba, SP. E-mail: admilson@sorocaba.unesp.br - ORCID: \\ 0000-0003-0655-6838 \\ ${ }^{4}$ ASSISTE Engenharia de Softwares. Piracicaba, SP. E-mail: angelo@assiste.com.br - ORCID: 0000-0002-3737-6082
}

\section{Key words:}

mechanical harvesting of sugarcane management of mechanization agricultural costs

\begin{abstract}
A B S T R A C T
In the mechanical harvesting of sugarcane, a self-propelled harvester is used in conjunction with an agricultural implement named infield wagon, which has the function of storing and transporting the harvested product. Much of the cost of sugarcane production comes from this operation (30 to 60\%). Among the operational costs of agricultural machinery, the cost of repair and maintenance (CRM) is relevant. Therefore, the objective of this study was to determine the parameters of the CRM mathematical model based on the life (hours of use) for the infield wagon, using the method of the American Society of Agricultural and Biological Engineers (ASABE). These CRM models were obtained for two sets of infield wagon from different manufacturers and their costs over up to 12 years. The model was adjusted and then validated using descriptive statistics methods. Fitted CRM equations were different for each analyzed set of infield wagon and, therefore, are a valuable tool in the management of mechanization in sugarcane mills as it provides elements that can support decision-making of managers in the acquisition and management of agricultural implements.
\end{abstract}

\section{Palavras-chave:}

colheita mecanizada da cana-deaçúcar gestão da mecanização custos agrícolas

\section{Gestão operacional do transbordo de cana-de-açúcar: Análise do custo de reparo e manutenção}

\section{R E S U M O}

Na colheita mecanizada de cana-de-açúcar é utilizada uma colhedora autopropelida em conjunto com uma máquina agrícola denominada de transbordo, que tem a função de transportar o produto colhido. Os custos com o corte, carregamento e transporte variam entre 30 e $60 \%$ dos custos de produção da cana-de-açúcar. Dentre os custos operacionais de máquinas agrícolas, o custo de reparo e manutenção (CRM) possui relevância, sendo assim, objetivou-se neste trabalho determinar os parâmetros do modelo matemático do CRM em função da vida (horas de uso) para o transbordo, utilizando o método da American Society of Agricultural and Biological Engineers (ASABE). Estes modelos de CRM foram obtidos para dois conjuntos de transbordos de fabricantes diferentes e seus dados despendidos ao longo de até 12 anos. O modelo foi ajustado e posteriormente validado utilizando métodos de estatística descritiva. As equações ajustadas do CRM foram diferentes para cada conjunto de transbordo analisado, sendo portanto, uma ferramenta importante na gestão da mecanização nas usinas pois fornece elementos que podem subsidiar as tomadas de decisão dos gestores na aquisição e gerenciamento de equipamentos agrícolas. 


\section{INTRODUCTION}

Self-propelled harvesters are not equipped with a tank that allows to store the sugarcane harvested; thus, they require a site to unload the product as they harvest. An agricultural vehicle, called infield wagon, has been developed for this purpose. It stores harvested sugarcane and takes it to the road transport, outside the crop area. These machines prevent road vehicles from traveling inside planting areas, minimizing damages caused by soil compaction (Severiano et al., 2010; Pacheco \& Cantalice, 2011; Araújo et al., 2013).

Santos et al. (2014) point out that the machines used in the mechanized harvesting system in sugarcane mills are considered as the most expensive among agricultural harvesting machines. Machinery costs are divided into costs of property (fixed) and operational or variable costs (Minette et al., 2008; Piacentini et al., 2012). The cost of repair and maintenance (CRM) is an operational cost difficult to quantify, because its data are dispersed in various sectors of the same agricultural company.

A mathematical model that relates CRM to a machine's life has been proposed by the American Society of Agricultural and Biological Engineers (ASABE, 2003). This model presents a method in which accumulated CRM (ARM) is used as a function of the machine's life. Parametrizations for this model, for various types of agricultural machinery, are presented in ASABE (2011). Nonetheless, parameters relative to sugarcane infield wagon are not presented.

Since agricultural mechanization has a continuous flow of development and creation of new technologies (Mercante et al., 2010), studies on the management of these machines are necessary. Baio et al. (2013) discuss the lack of information on costs for machinery used in Brazil. Studies on CRM are important to support the decision-making of companies' managers (Silveira et al., 2006). Management of fleets of machines has become increasingly present in the planning of agricultural operations, because a larger volume of data is collected by the production sector (Sichonany et al., 2012). This study aimed to fit a mathematical model to calculate the ARM, as proposed by ASABE, for agricultural infield wagons, as a function of life (hours of use) and verify its application for groups of vehicles in the same category.

\section{Material ANd Methods}

Data were collected in an agricultural company located in the region of Ribeirão Preto- SP, Brazil ( $-21^{\circ} 10^{\prime}$ S; $\left.-47^{\circ} 48^{\prime} \mathrm{W}\right)$, which delivers in its processing unit, on average, 4 to 5 thousand tons of sugarcane per day. Data composing the CRM were collected by a computerized fleet control system (SISMA', of the Assiste Engenharia de Softwares Técnicos). These pieces of information were generated by various sectors of the sugarcane mill and the data of each vehicle were stored in databases. This study used data from 11 infield wagons of the fleet of a mill, from two different manufacturers, 4 vehicles of brand A, year of manufacture 2001, which started operating in the 2002 season, with 12 years of observation, and 7 vehicles of brand B, year of manufacture 2005, which started operating in the
2005 season, with 9 years of observation. The models have 8-ton load capacity, two axles and equal hydraulic lift system for unloading, and thus are characterized as similar.

CRM calculations, used to parametrize the model proposed by ASABE, followed the method proposed by Banchi et al. (2008), composed by various types of costs, as described in Eq. 1. The terms in the equation are given in Reais $(\mathrm{R} \$)$ per unit of time. In the months of calculation of these costs, apportionments refer to parts and labor that cannot be directly allocated to one vehicle.

$$
\mathrm{CRM}=\mathrm{CPC}+\mathrm{CLC}+\mathrm{COP}+\mathrm{COL}+\mathrm{AP}+\mathrm{AL}+\mathrm{CT}
$$

where:

CPC - costs with parts from the company's stock;

CLC - costs with labor of mechanics from the company;

COP - expanses with outsourced parts, purchased from other company;

COL - costs with outsourced labor, mechanics of other company;

AP - apportionment of parts;

AL - apportionment of labor; and,

CT - costs with tires.

Since these values are considered over time, monetary correction becomes necessary. The correction index used was the Extended National Consumer Price Index (IPCA), considered as the official inflation rate in the country. Monthly accumulated data for each vehicle were updated and summed for each end of year, expressing the annual accumulation, which is CRM. These annual costs were updated for a reference date. Therefore, values were monetarily corrected and with the same reference date, so the sum of the annual values is defined as accumulated cost of repair and maintenance (ARM).

The infield wagon's life was quantified in hours of use and its mean time of use per year was calculated based on the mean of hours shown by the tractors with which it worked. Hence, a value of 1,850 h of use year-1 was found for each infield wagon.

The method used to relate ARM to a machine's life was proposed by ASABE, which calculates ARM as a function of the price of acquisition of the infield wagon (PAC), corrected by the inflation, of the accumulated use in hours (AH) and of two specific parameters for each type of machine, RF1 and RF2, for a life (n), according to Eq. 2. This procedure has been detailed by Kastens (1997).

$$
\mathrm{ARM}_{\mathrm{n}}=\mathrm{RF} 1 \mathrm{PAC}_{\mathrm{n}}\left(\mathrm{AH} \mathrm{10} 0^{-3}\right)^{\mathrm{RF} 2}
$$

As can be seen in the equation proposed by ASABE and in the study of Wahby \& Suhaibani (2001), the model with best fit is the exponential. These authors demonstrated that, when the machines are separated by a certain characteristic, the regressions show a better correlation between the data, compared with the database without grouping.

Since the exponential function was used, a base-10 log transformation was carried out in both data sets of accumulated cost of repair and maintenance (ARM PAC ${ }^{-1}$ ), by the accumulated use of the machine $\left(\mathrm{AR} 10^{-3}\right)$, Eq. 3. With 
these transformed data, a linear regression was performed to find the parameters of the model, Eq. 4.

$$
\log \left(\mathrm{ARM} \mathrm{PAC}^{-1}\right)=\mathrm{a} \log \left(\mathrm{AR} 10^{-3}\right)+\mathrm{b}
$$

Applying antilog in the equation leads to:

$$
\mathrm{ARM} \mathrm{PAC}^{-1}=\mathrm{RF} 1\left(\mathrm{AR} 10^{-3}\right)^{\mathrm{RF} 2}
$$

where:

$$
\begin{aligned}
& \text { RF1 - } 10^{\text {b }} \text {; and, } \\
& \text { RF2 - a. }
\end{aligned}
$$

To fit the model according to the method of ASABE, it was necessary to obtain the values paid to purchase the vehicles: $\mathrm{R} \$ 47,000.00$ for the one of brand A, year of manufacture 2001, and $R \$ 63,000.00$ for the one of brand $B$, year of manufacture 2005. These values were obtained at the agricultural company and, when corrected by the IPCA, demonstrate equality, reinforcing the similarity between machines of different brands.

Parametrization and fits of the models were validated using the ANOVA Table, showing the F test, graph of residuals, coefficient of correlation $\mathrm{R}$, and the coefficient of determination $\mathrm{R}^{2}$, to analyze the model to be adopted (software $\mathrm{R}$ ).

\section{Results AND Discussion}

Figures $1 \mathrm{~A}$ and $\mathrm{B}$ present the curves of correlation between ARM PAC ${ }^{-1}$ values after applying base-10 logarithm,
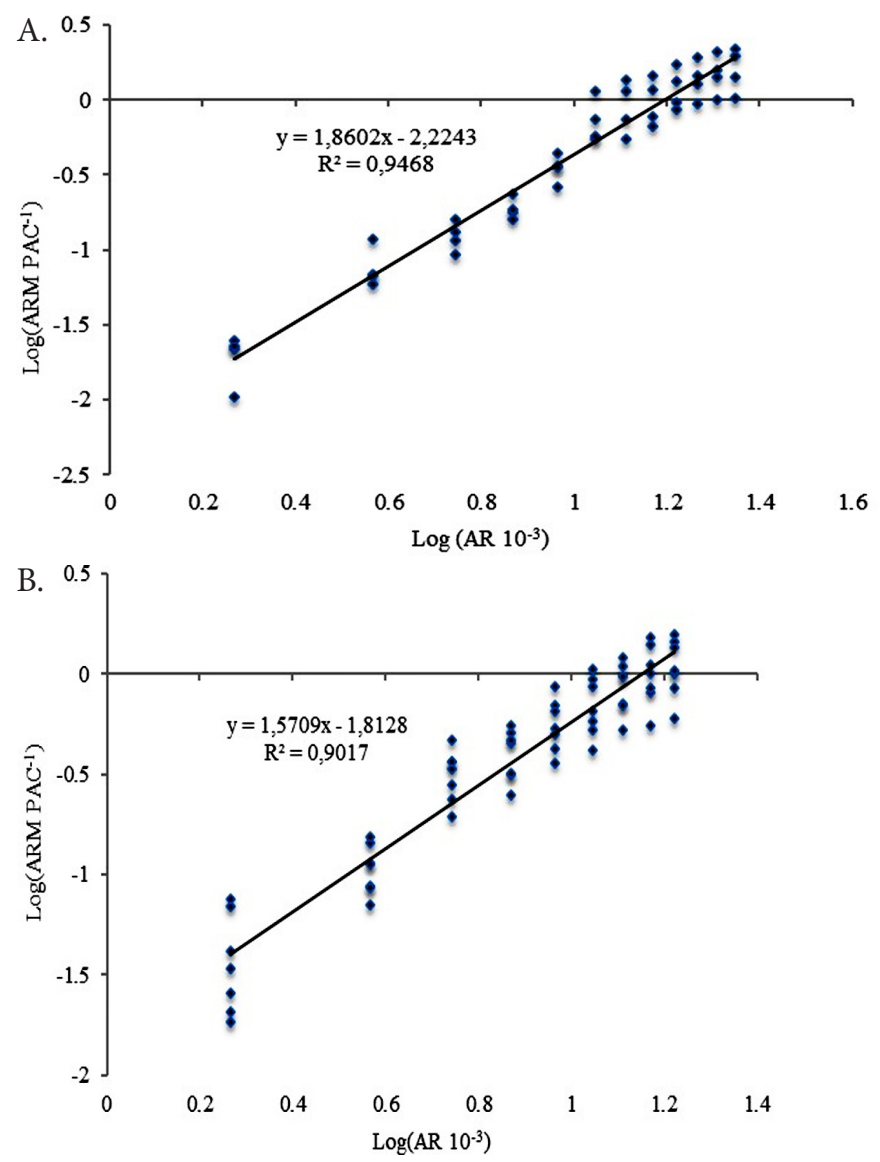

Figure 1. Scatter plot for the infield wagons: (A) brand A; (B) brand B linear regression equations and coefficients of determination $\left(\mathrm{R}^{2}\right)$.

Data of the brand-A vehicles (Figure 1A) showed correlation coefficient $\mathrm{r}=0.973$, whereas brand-B vehicles (Figure 1B) showed correlation coefficient $r=0.949$, which indicates a linear association between the data. The residuals obtained from the regression curves were then analyzed. Errors are independent and normally distributed, Figures $2 \mathrm{~A}$ and B, with no bias. Therefore, the model can be considered as valid.

Analysis of variance (Table 1) was conducted with the null hypothesis of rejecting $\mathrm{H} 0$ : $\mathrm{p}$-value $=0$. If the calculated $\mathrm{p}$-value is different from zero, the $\mathrm{H} 0$ hypothesis is rejected. Therefore, the regression is significant.

According to the presented model, the determination coefficient, $\mathrm{R}^{2}$, was equal to $94.68 \%$ for brand-A vehicles and to $90.16 \%$ for brand-B vehicles. Based on the coefficients, the model was adequate. The data obtained by the linear regressions were used to make the necessary transformations, shown in Eq. 4 , to find the parameters of the models for brand-A vehicles, Eq. 5, and brand-B vehicles, Eq. 6.

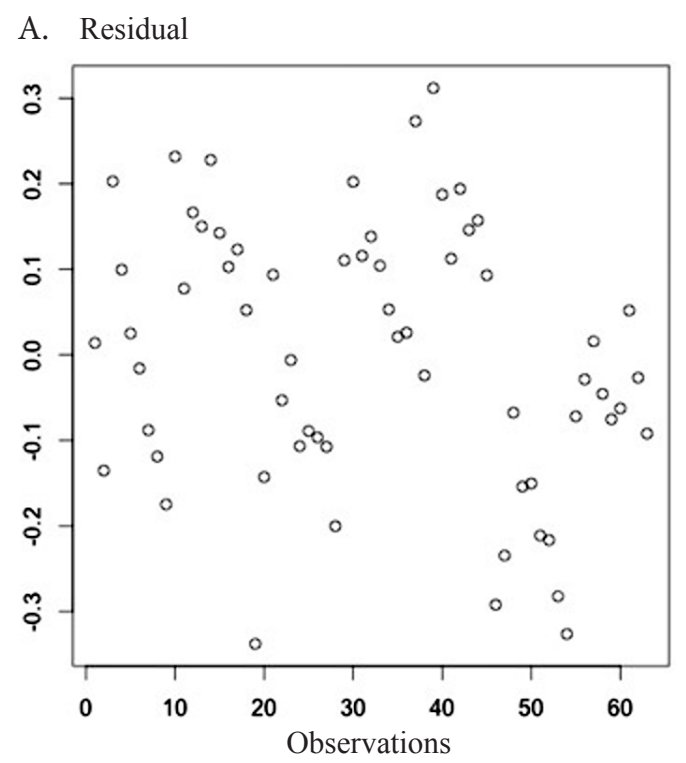

B. Residual

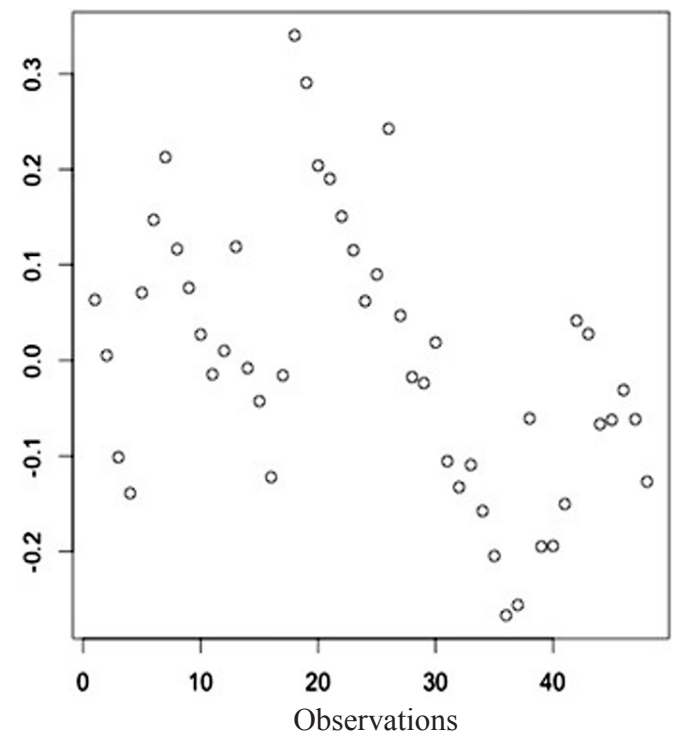

Figure 2. Graph of residuals of the regressions for brand-A (A) and brand-B (B) vehicles 
Table 1. ANOVA for brand-A (A) and brand-B (B) vehicles

\begin{tabular}{ccccccc}
\hline & $\begin{array}{c}\text { Source } \\
\text { of variation }\end{array}$ & $\begin{array}{c}\text { Degrees } \\
\text { of freedom }\end{array}$ & $\begin{array}{c}\text { Quadratic } \\
\text { sum }\end{array}$ & $\begin{array}{c}\text { Quadratic } \\
\text { mean }\end{array}$ & $\mathrm{F}_{0}$ & p-value \\
A. & Regression & 1 & 16.407 & 16.41 & 818 & $2 \mathrm{e}-16$ \\
& Error & 46 & 0.923 & 0.02 & & \\
B. & Regression & 1 & 13.484 & 13.484 & 559.3 & $2 \mathrm{e}-16$ \\
\hline & Error & 61 & 1.471 & 0.024 & & \\
\hline
\end{tabular}

$$
\begin{aligned}
& \mathrm{ARM}_{\mathrm{n}}=0.006 \cdot \mathrm{PAC}_{\mathrm{n}} \cdot\left(\frac{\mathrm{AH}}{1,000}\right)^{1.860} \\
& \mathrm{ARM}_{\mathrm{n}}=0.015 \cdot \mathrm{PAC}_{\mathrm{n}} \cdot\left(\frac{\mathrm{AH}}{1,000}\right)^{1.571}
\end{aligned}
$$

The same procedure was used for the entire set of points, finding Eq. 7, which is the general model of both types of vehicle. Figure 3 shows the graph with the three equations.

$$
\mathrm{ARM}_{\mathrm{n}}=0.011 \cdot \mathrm{PAC}_{\mathrm{n}} \cdot\left(\frac{\mathrm{AH}}{1,000}\right)^{1.667}
$$

It can be observed in Eqs. 5, 6 and 7 that the parameters are affected by the brand of the vehicles. The factor RF1 varies from 0.006 to 0.015 and the factor RF2 varies from 1.860 to 1.571, which significantly affects ARM value, indicating that, along the life, the accumulated cost of repair and maintenance will be higher for brand-A vehicles. A simulation was carried out for three values of life: initial, with 1,850 h; intermediate, with $9,250 \mathrm{~h}$ and final, with $16,650 \mathrm{~h}$. According to the ARM $\mathrm{PAC}^{-1}$ values, for both brands studied, there were differences of costs in the initial point of $115 \%$, in the intermediate point of $35 \%$ and in the final point of $14 \%$, and brand-B vehicles always showed lower ARM $\mathrm{PAC}^{-1}$ values compared with brand A. Since the vehicles are similar in terms of load capacity, number of axles, unload system with hydraulic lift and prices of acquisition (PAC), it can be inferred that the materials composing the vehicles have different quality or that an alteration in the manufacturing process leads to a decrease in the resistance of some component. Such information is important in machinery management, since there are many manufacturers in the market, and can be relevant in the choice of the next acquisitions of infield wagons.

The standard error of each set of values (Table 2) was obtained by using the standard error of the estimates of the

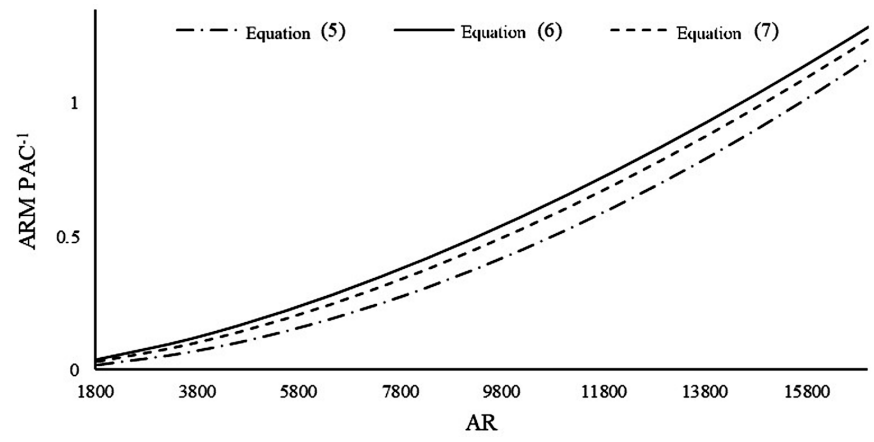

Figure 3. ARM obtained through Eqs. 5, 6 and 7, for the models A, B and general, respectively
Table 2. Standard error of the estimate for the general model (Eq. 7) and the specific model of each brand

\begin{tabular}{ccc}
\hline & General model (Eq. 7) & Specific model (Eqs. 5 and 6) \\
Brand A & 1.0715 & 1.0471 \\
Brand B & 1.0677 & 1.0570 \\
\hline
\end{tabular}

brands, which allows to measure the mean deviation between actual values and values estimated by the model, the actual values for each brand applied in Eq. 7 and applied in the specific equations of each brand, Eqs. 5 and 6.

It can be noted that, as the data of the vehicles were grouped by brand, a better fit of the models was obtained, because the standard errors are lower than the calculated ones for the model generated by all points, which is consistent with the results presented by Wahby \& Suhaibani (2001). These authors concluded that grouping machinery by homogeneous category (brand) tends to provide better fitted models.

The present study demonstrates that there is a variation of behavior among the models of machines, a fact not distinguished by ASABE, which shows general values for a range of machines and does not consider the differences between models and brands, as evidenced in the publication table of ASABE (2011).

\section{Conclusions}

1. There is a correlation between CRM and infield wagon's life, and it is possible to fit a mathematical model, as described by ASABE, for the infield wagon.

2. This method of data analysis may assist in machinery management, since machines that are similar, but from different brands, exhibit different costs of repair.

3. Specific mathematical models for groups of machines, with similar characteristics, lead to more consistent results compared with general mathematical models.

\section{Acknowledgments}

To the Coordination for the Improvement of Higher Education Personnel (CAPES) for the scholarship and to the ASSISTE Engenharia de Softwares Técnicos for providing the data and information about the SISMA.

\section{Literature Cited}

Araújo, F. S.; Souza, Z. M. de; Souza, G. S. de; Matsura, E. E.; Barbosa, R. S. Espacialização do intervalo hídrico ótimo de um Latossolo Vermelho em dois sistemas de colheita de cana-de-açúcar. Pesquisa Agropecuária Brasileira, v.48 p.651-660. 2013. https:// doi.org/10.1590/S0100-204X2013000600011

ASABE - American Society of Agricultural and Biological Engineers. Agricultural machinery management data. St. Joseph: ASABE, 2003. 370p. ASABE standards D 496.2

ASABE - American Society of Agricultural and Biological Engineers.

Agricultural machinery management data. St. Joseph: ASABE, 2011. 6p. ASABE standards D 497.7 
Baio, F. H. R.; Rodrigues, A. D.; Santos, G. S. dos; Silva, S. P. da. Modelagem matemática para seleção de conjuntos mecanizados agrícolas pelo menor custo operacional. Engenharia Agrícola, v.33, p.402-410, 2013. https://doi.org/10.1590/S010069162013000200018

Banchi, A. D.; Lopes, J. R.; Zago, C. A. Estudo dos custos com reparo e manutenção em colhedoras de cana-de-açucar, parte I. Revista Agrimotor, v.1, p.12-13, 2008.

Kastens, T. Farm machinery operation cost calculations. Manhattan: Kansas State University, 1997. 24p. Extension Agricultural Economist

Mercante, E.; Souza, E. G. de; Johann, J. A.; Gabriel Filho, A.; UribeOpazo, M. A. PRAPRAG-Software para planejamento racional de máquinas agrícolas. Engenharia Agrícola, v.30, p.322-333, 2010. https://doi.org/10.1590/S0100-69162010000200015

Minette, L. J.; Silva, E. N. da; Freitas, K. E. de; Souza, A. P. de; Silva, E. P. Análise técnica e econômica da colheita florestal mecanizada em Niquelândia, Goiás. Revista Brasileira de Engenharia Agrícola e Ambiental, v.12, p.659-665, 2008. https://doi.org/10.1590/S141543662008000600014

Pacheco, E. P.; Cantalice, J. R. B. Compressibilidade, resistência a penetração e intervalo hídrico ótimo de um Argissolo Amarelo cultivado com cana-de-açúcar nos tabuleiros costeiros de Alagoas. Revista Brasileira de Ciência do Solo, v.35, p.403-415, 2011. https://doi.org/10.1590/S0100-06832011000200010
Piacentini, L.; Souza, E. G. de; Uribe-Opazo, M. A.; Nóbrega, L. H. P.; Milan, M. Software para estimativa do custo operacional de máquinas agrícolas - MAQCONTROL. Engenharia Agrícola, v.32, p.609-623, 2012. https://doi.org/10.1590/S0100-69162012000300020

Santos, N. B.; Silva, R. P.; Gadanha Júnior, C. D. Economic analysis for sizing of sugarcane (Saccharum spp.) mechanized harvesting. Engenharia Agrícola, v.34, p.945-954, 2014. https://doi. org/10.1590/S0100-69162014000500013

Severiano, E. da C.; Oliveira, G. C. de; Dias Júnior, M. de S.; Castro, M. B. de; Oliveira, L. F. C. de; Costa, K. A. de P. Compactação de solos cultivados com cana-de-açúcar: II-Quantificação das restrições às funções edáficas do solo em decorrência da compactação prejudicial. Engenharia Agrícola, v.30, p.414-423, 2010. https:// doi.org/10.1590/S0100-69162010000300006

Sichonany, O. R. de A. O.; Schlosser, J. F.; Medina, R. D.; Roggia, I. B.; Lôbo, J. S.; Santos, F. B. dos. Telemetria na transmissão de dados de desempenho de máquinas agrícolas utilizando tecnologia GSM/ GPRS e ZigBee. Ciência Rural, v.42, p.1430-1433, 2012. https:// doi.org/10.1590/S0103-84782012000800016

Silveira, G. M. da; Yanai, K.; Kurachi, S. A. H. Determinação da eficiência de campo de conjuntos de máquinas convencionais de preparo do solo, semeadura e cultivo. Revista Brasileira de Engenharia Agrícola e Ambiental, v.10, p.220-224, 2006. https:// doi.org/10.1590/S1415-43662006000100032

Wahby, M. F.; Suhaibani, S. A. Repair and maintenance cost models for agricultural equipment in Saudi Arabia. In: ASAE Annual International Meeting, Sacramento, California, USA, 2001. 19p. 